\title{
Botulism in ruminants in Brazil
}

\author{
Botulismo em ruminantes no Brasil
}

\author{
Rodrigo Otávio Silveira Silva ${ }^{\mathrm{I}^{*}}$ Carlos Augusto Oliveira Junior ${ }^{\mathrm{I}}$

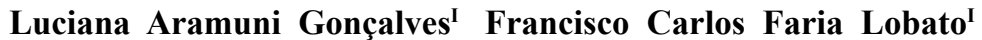

\section{- REVIEW -}

\section{ABSTRACT}

Botulism is an intoxication caused by the ingestion of neurotoxins secreted by Clostridium botulinum. It affects all warm-blooded animals and some fishes and is characterized by progressive flaccid symmetrical paralysis. Despite the known importance of this disease in ruminants, the Brazilian literature only includes case studies and outbreak descriptions. In addition, the epidemiology of botulism in cattle has markedly changed over the past two decades. The aim of this study is to review these characteristics and to provide recent data on the occurrence of botulism in ruminants in Brazil.

Key words: flaccid paralysis, Clostridium botulinum, cattle, buffaloes, goats, sheep.

\section{RESUMO}

O botulismo é uma intoxicação causada pela ingestão das neurotoxinas secretadas por Clostridium botulinum. A doença afeta todos os animais de sangue quente e alguns tipos de peixes, sendo caracterizada por uma paralisia flácida simétrica progressiva. Apesar da reconhecida importância dessa doença nos ruminantes, a literatura brasileira baseia-se apenas em relatos de casos e descrições de surtos. Além disso, a epidemiologia do botulismo em bovinos apresentou marcantes alterações nas últimas duas décadas. Dessa forma, é essencial uma revisão que elucide as principais características da doença em animais no Brasil. O presente trabalho tem como objetivo revisar tais caracteristicas, além de fornecer dados recentes sobre a sua ocorrência em ruminantes.

Palavras-chave: paralisia flácida, Clostridium botulinum bovinos, búfalos, ovinos, caprinos.

\section{INTRODUCTION}

Botulism, derived from the Latin botulus (sausage), was described for the first time in Germany in 1820 , following several cases of flaccid paralysis in humans associated with the ingestion of sausages and meat sauces (LEDERMANN, 2003). The disease results from intoxication or, in rare cases, from tox infection and affects humans and several other animal species (LOBATO et al., 2013).

The causative agent of botulism is Clostridium botulinum, a Gram-positive rod-shaped and strictly anaerobic bacterium that is a normal soil inhabitant and can sporulate in adverse conditions. This microorganism can grow in different types of substrates as long as there is a favorable anaerobic environment that allows its multiplication. Eight types of $\boldsymbol{C}$. botulinum have been described (A, B, $\mathrm{C}, \mathrm{D}, \mathrm{E}, \mathrm{F}, \mathrm{G}$ and $\mathrm{H}$ ). Types $\mathrm{C}$ and $\mathrm{D}$ are mainly responsible for botulism in animals, with few cases being caused by the remaining types (LOBATO et al., 1988; LOBATO et al., 2008; LOBATO et al., 2013). Type $H$ has been recently described, but no animal intoxications have yet been reported (DOVER et al., 2014).

Botulinum neurotoxins are the strongest known microbial toxins. They are formed by two peptide chains, one heavy chain $(100 \mathrm{kDa})$ and one light chain $(50 \mathrm{kDa})$, linked by a disulfide

IEscola de Veterinária, Universidade Federal de Minas Gerais (UFMG), Avenida Antônio Carlos, 6627, 31270-901, Belo Horizonte, MG, Brasil. E-mail: rodrigo.otaviosilva@gmail.com. *Corresponding author. 
bond. Following their ingestion by animals, the botulinum toxins resist proteolytic degradation in the gastrointestinal tract, are absorbed by the intestinal mucosa, and act on neuromuscular junctions. Neurotoxins enter motor neurons at the neuromuscular junctions through endocytosis. Heavy chains then form pores through which the light chains enter the cytosol of the neuron. Light chains then cleave one or more proteins responsible for the release of excitatory neurotransmitters at the neuromuscular junctions (AOKI et al., 2010). This release results in the inability to perform muscle contraction or the characteristic ascending flaccid symmetrical paralysis. Because botulinum toxins only act on the peripheral nervous system, affected animals have unchanged consciousness or mental status (LOBATO et al., 2013).

In Brazil, botulism cases are extremely important in ruminants, common in birds and dogs, and have also been described for other species, namely dogs, pigs, horses and wild mammals (CUBAS, 1996; COELHO et al., 2000; RAYMUNDO et al., 2012a). In spite of the known importance of botulism in ruminants, the Brazilian literature is limited to case studies and outbreak descriptions. In addition, the epidemiology of botulism in cattle has markedly changed over the past two decades. Therefore, the aim of this study was to review these characteristics and to provide recent data on botulism occurrence in ruminants in Brazil.

Botulism in cattle and other domestic ruminants

Botulism was first described in cattle in Brazil in the 1960s in the state of Piauí (TOKARNIA et al., 1970) and was later diagnosed in all Brazilian regions and in other species, such as sheep, goats and buffaloes (Table 1) (LANGENEGGER \& DÖBEREINER, 1988; LOBATO et al., 2007). Starting in the 1970s, botulism cases in cattle exponentially increased, especially due to historical changes in cattle farming in Brazil. Replacement of native vegetation with exotic grass species that are less demanding and able to grow in phosphorus-poor soils, such as species from the genus Brachiaria, allowed the expansion of cattle raising, especially beef cattle, into Cerrado (Brazilian savanna) areas (ARRUDA, 1994). In addition to this expansion into poor soils, there was a constant genetic improvement of Brazilian cattle, largely promoted by the government, resulting in increasingly nutritionally demanding animals. High-yield cattle, with high nutritional demands, that ingested calcium- and phosphorus-poor plants and that were not supplied with the correct mineral supplements developed osteophagia or sarcophagia, a depraved appetite in which the animals ingest bones or carcasses present in pastures in an attempt to satisfy their mineral needs.

These factors were very clearly present from the 1970s to the 1990s, when botulism was endemic and caused high cattle mortality. Botulism cases mainly occurred in the beginning of the rainy season, when births are concentrated, and in pregnant and newly calved cows, which have higher calcium and phosphorus demands (DUTRA \& DOBEREINER, 1995). It has been estimated that between the 1970s and 1990s, over two million cattle died as a result of "downer cow disease" (CARCIOFI et al., 2003). During this period, in addition to botulism, several other etiologies, such as malnutrition, mineral deficiencies and fluoride intoxication, were indicated as causing this disease (ORTOLANI, 1993). However, an epidemiological study performed with the goal of determining the etiology of "downer cow disease" confirmed botulism as the most frequent cause of the clinical signs presented by the studied animals (CARCIOFI et al., 2003), indicating the need for improving the prevention and control of botulism. Identification of botulism, implementation of its diagnosis, and diffusion of prophylactic control measures were essential for the gradual decrease in the occurrence of osteophagia-associated botulism in cows. Currently, this type of botulism still occurs and have been reported in some farms in northeast of Brazil, due the lack of mineral supplementation and/or absence immunization against botulinic toxin. In the Midwest, where there is the largest national contingent of extensive beef cattle production, are also reported outbreaks of botulism related to osteophagia due the difficulty to provide adequate mineral supplementation for animals created over large areas. Of the 22 outbreaks reported by LEMOS (2005), 16 of them were caused mainly by osteophagia. Despite this, botulism outbreaks associated with contaminated feed increases proportionally matters, becoming responsible for most reports from the 1990s (LOBATO et al., 2008). Sources of Botulism outbreaks commonly reported over the past two decades include food supplements, poorly packaged silage or silage contaminated with small animal carcasses (cats, rodents and birds), and poultry litter, one of the main causes of outbreaks to date (SCHOCKEN-ITURRINO \& AVILA, 1991; ORTOLANI et al., 1997; LEMOS, 2005; DUTRA et al., 2005; LOBATO et al., 2008; COSTA et al., 2008; CÂMARA et al., 2011; RIBAS et al., 2013; CÂMARA et al., 2014; RAYMUNDO et al., 2014). Use of poultry 
Table 1 - Main reported botulism outbreaks in ruminants in Brazil (1960 to 2016).

\begin{tabular}{|c|c|c|c|c|c|c|}
\hline Year & States & Species affected & $\begin{array}{l}\text { Number of } \\
\text { affected }\end{array}$ & Lethality (\%) & $\begin{array}{l}\text { Main source of } \\
\text { toxins }\end{array}$ & References \\
\hline $\begin{array}{l}1960- \\
1980\end{array}$ & PI & Cattle & 2000 to 3000 & $>90,0$ & Osteophagia & TOKARNIA et al. (1970) \\
\hline $\begin{array}{l}1980- \\
1990\end{array}$ & $\begin{array}{l}\text { SP, MS, } \\
\text { MG }\end{array}$ & Cattle & \pm 3000 & 100,0 & $\begin{array}{l}\text { Water and Poultry } \\
\text { Litter }\end{array}$ & DUTRA et al., $(2001,2005)$ \\
\hline $\begin{array}{l}1990- \\
2000\end{array}$ & SP, MG & Cattle & \pm 600 & 60.5 to 100,0 & $\begin{array}{l}\text { Water, carcasses } \\
\text { and poultry Litter }\end{array}$ & $\begin{array}{l}\text { ORTOLANNI et al., (1997); DUTRA et } \\
\text { al., (2001, 2005); }\end{array}$ \\
\hline $\begin{array}{l}2000- \\
2010\end{array}$ & $\begin{array}{l}\text { MS, PB, } \\
\text { MG, PA, } \\
\text { RS, PE, } \\
\text { RN, SP }\end{array}$ & $\begin{array}{l}\text { Cattle, Goats, } \\
\text { Sheep and } \\
\text { Buffaloes }\end{array}$ & \pm 1000 & 50 to 1000 & $\begin{array}{l}\text { Poultry Litter, } \\
\text { Silage, } \quad \text { Water, } \\
\text { Osteophagia }\end{array}$ & $\begin{array}{l}\text { LEMOS, (2005); LOBATO et al. (2008); } \\
\text { COSTA et al. (2008); MABONI et al. } \\
\text { (2010); ALBERNAZ et al. (2011); } \\
\text { VELOSO NETO et al. (2011); } \\
\text { CÂMARA et al. (2014) }\end{array}$ \\
\hline $\begin{array}{l}2010- \\
2015\end{array}$ & PI, RN & Goats Cattle & \pm 100 & 97,4 to 100 & $\begin{array}{l}\text { Poultry litter, } \\
\text { osteophagia }\end{array}$ & $\begin{array}{l}\text { RIET-CORREA et al. (2012); CÂMARA } \\
\text { et al. (2014) }\end{array}$ \\
\hline
\end{tabular}

litter in ruminant feeding was prohibited in 2004 due to the risk of bovine spongiform encephalopathy (BSE) (BRASIL, 2009), but it is still commonly used in cattle farming in Brazil, especially in dairy farms in the southeast and south of the country.

Other common toxin sources for cattle, which have also been reported for buffaloes, are stagnant water sources, such as swales, rain water harvesting ditches and small lagoons (SILVA et al., 1998; SOUZA et al., 2006). Presence of slime and other sources of organic matter in these sites may favor the multiplication of $\boldsymbol{C}$. botulinum and can result in isolated cases to high-mortality outbreaks of botulism. Such was the case of a large outbreak that occurred in Mato Grosso do Sul (MS) in 1989, affecting over 2500 cattle (COELHO et al., 1996; DUTRA, 1990; DUTRA et al., 2001; ALBERNAZ et al., 2011). Again in MS, LEMOS (2005), reported 22 outbreaks of botulism in cattle from 2000 to 2003, five $(23.8 \%)$ due to ingestion of contaminated water.

Botulism morbidity rate in cattle farms varies from 0.1 to $100 \%$ and is closely related to the herd's vaccination coverage; however, the case fatality rate for botulism is always close to $100 \%$, resulting in significant losses (CARCIOFI et al., 2003; DUTRA et al., 2005; CÂMARA et al., 2014). In a differential diagnosis study of 1431 cattle presenting neurological signs between 2000 and 2003 in the state of Mato Grosso do Sul, rabies and botulism were the two main diagnosed diseases, corresponding to $13 \%$ and $10 \%$ of the animals, respectively (LEMOS, 2005). In a retrospective study of 588 cattle presenting neurological signs between 2008 and 2012, which was also conducted in the state of Mato Grosso do Sul, the most frequently confirmed disease was botulism $(16.67 \%)$, ahead of rabies (15.92\%), polioencephalomalacia (8.05\%), and herpes meningoencephalitis (4.31\%) (RIBAS et al., 2013). These data suggested that although botulism has been known for over four decades and its incidence has decreased markedly compared to the 1970s-1990s, it still presents high occurrence rates, causing high losses to rural producers (RAYMUNDO et al., 2014).

Cattle are mainly susceptible to neurotoxins $\mathrm{C}$ and $\mathrm{D}$ and are rarely affected by types $A$ and B (KRÜGER et al., 2012). The incubation period in cattle varies from a few hours to over a week. Because the course of the intoxication is dosedependent, the herd's more voracious, dominant animals with larger appetites are often the first to present clinical signs during outbreaks, with more acute disease presentations (LOBATO et al., 2008; LOBATO et al., 2013).

Initially, the affected animals present locomotion difficulty, a lack of coordination of the pelvic limbs, and stiff movement of the thoracic limbs as an attempt to compensate for the lack of coordination of the pelvic limbs. The flaccid paralysis progresses cranially, and the mental status 
of the animals remains unchanged. Marked decreases in sensory reflexes in the lumbosacral and perianal regions, tongue hypotonia and flaccid tail develop. As the disease progresses, the animals present respiratory difficulty and enter into a preagonal state. Death occurs through cardiopulmonary arrest due to paralysis of the respiratory muscles. Although botulism is usually an acute disease in animals, recently some cases of chronic botulism has been described in European countries (RODLOFF \& KRÜGER, 2012). This rare form of the disease, also known as "visceral botulism", is still poorly understood and might be linked to the intestinal microbiota dysbiosis and trace element deficiency (RODLOFF \& KRÜGER, 2012; KRÜGER et al., 2012; KRÜGER et al., 2014).

Similarly to other species, necropsy commonly reveals no post mortem lesions. In botulism cases associated with osteophagia, bone remains are commonly found in the animals' stomachs, which increases the suspicion of intoxication due to botulinum toxins (LOBATO et al., 2008; LOBATO et al., 2013; CÂMARA et al., 2014;). Treatment of botulism in cattle is based on the administration of botulinum antitoxin serum. However, this therapy has low efficacy because ruminants are extremely sensitive to botulinum toxin, requiring the application of antiserum as quickly as possible, which is not always viable (ANNIBALLI et al., 2013). The fact that large numbers of animals are affected in disease outbreaks also makes the treatment practically impossible on commercial farms, and euthanasia is generally applied.

Botulism has also been reported in other domestic ruminants in Brazil, namely goats, sheep and buffaloes (COELHO et al., 1996; LOBATO et al., 2008; RIET-CORREA et al., 2012), with very similar predisposing factors as the ones described for cattle (ALBERNAZ et al., 2011; NOVAIS, 2013). In small ruminants, botulism is more common in sheep than in goats. The analysis of neurological signs presented by sheep and goats sent to the Large Animal Veterinary Hospital of the Universidade de Brasília between 2001 and 2012 revealed a botulism frequency of $16.2 \%$ in sheep, whereas no goats were diagnosed with the disease (NOVAIS, 2013). Although less important than in cattle, osteophagia associated with calcium and phosphorus deficiency can also result in botulism in other ruminants (RIET-CORREA et al., 2012). Highmortality outbreaks in small ruminants have also been reported in Brazil (Table 1), with an outbreak reported in Paraíba associated with the ingestion of poultry litter standing out, as it resulted in the death of 378 goats and sheep (LOBATO et al., 2008).
Diagnosis

The presumptive diagnosis of botulism in animals is based on the combination of individual and herd histories and characteristic clinical signs. Typically, no significant changes are observed post mortem, but the presence of bones in the rumen and reticulum may indicate botulism due to osteophagia. Laboratory confirmation is obtained through the detection and identification of botulinum toxin(s) in clinical specimens using serum neutralization tests in mice (LOBATO et al., 2013).

Two factors that are essential to increase the predictive value of botulism diagnosis are the sampling of animals with higher probability of toxin detection and the adequate collection of clinical specimens. Regardless of the species, in outbreaks, it is essential to collect material from animals presenting shorter incubation times and acute disease courses, indicating higher ingestion of botulinum toxin. Animals that died more than 3 hours before collection should be avoided because toxin degradation may begin to occur from that time on, which would undermine the diagnosis (LOBATO et al., 2007; LOBATO et al., 2013).

In cattle, due to their very high sensitivity, detection of botulinum toxin in blood serum is difficult and occurs almost exclusively in recently intoxicated animals with extremely acute disease presentation. Therefore, the main goal in cattle is to identify the toxin before it reaches the bloodstream, which makes the liver and the stomach and intestinal contents the preferred specimens for toxin detection (ANNIBALLI et al., 2013; LOBATO et al., 2013). Clinical samples for detection of botulinum toxin should be sent to the laboratory under refrigeration. At least $2 \mathrm{~mL}$ of blood serum, $100 \mathrm{~g}$ of liver fragments and $50 \mathrm{~g}$ of duodenal and abomasum contents should be sent. It is important to note that the stomach and intestinal contents should be drained and sent in vials. Sending the contents inside the organs may increase the chance of false-negative results, as proteases may degrade the toxins. Food and water suspected of being intoxication sources can also be sent for toxin detection under refrigeration (LOBATO et al., 2007). Currently, the Laboratório Nacional Agropecuário (LANAGRO, MG - Pedro Leopoldo) performs free analyses of botulinum toxins in animal and food samples. Serum neutralization test in mice (or mice bioassay) is still the standard technique to diagnosis botulism in animals in Brazil. It is important to note that several studies have shown that some in vivo techniques, including enzyme immunoassays (ELISA) to detect botulinum toxin in clinical 
specimens and real time PCR to detect $\boldsymbol{C}$. botulinum DNA, could be viable alternatives to the currently used animal model to diagnose botulism in animals (KRÜGER et al., 2014; SOUILLARD et al., 2015).

Rabies should be the main differential diagnosis. It is important to note that the mental status remains unchanged in botulism, whereas rabies causes some behavioral abnormalities (LOBATO et al., 2007; PEDROSO et al., 2009). Other differential diagnoses in cattle include bovine herpesvirus 5 encephalitis; listeriosis; toxicosis caused by ticks; polioencephalomalacia; hypocalcemia; hypomagnesemia; intoxications by lead, sodium chloride, organophosphates and chlorinated hydrocarbons; ingestion of mycotoxins produced by Aspergillus clavatus (known as the barley fungus); and ingestion of plants from genus Senna spp. (LOBATO et al., 2007; ANNIBALLI et al., 2013; CARVALHO et al., 2014).

Prevention and control

Vaccination with $\boldsymbol{C}$. botulinum toxoids is the main prevention measure of botulism in cattle (LOBATO et al., 2013; CÂMARA et al., 2014). Commercialization of $\boldsymbol{C}$. botulinum type $\mathrm{C}$ and $\mathrm{D}$ toxoids began in the $1980 \mathrm{~s}$, but studies performed in the beginning of the 1990s revealed the low quality of these immunogens that were commercialized in Brazil (LOBATO et al., 1998). As a result, since 1997, the potency of commercial vaccines containing C. botulinum types C and D toxoids is systematically evaluated by the Ministério da Agricultura Pecuária and Abastecimento (BRASIL, 1997), which guarantees their quality.

In addition to vaccination, other basic measures for the prevention of botulism in cattle are the supply of balanced minerals, safe water and high-quality feed; not using poultry litter in animal production; and care during silage and feed preparation and stocking to avoid accidental incorporation of animal carcasses, especially of birds and rodents (LOBATO et al., 2007; ANNIBALLI et al., 2013; LOBATO et al., 2013). It is also important to decrease environmental contamination by $\boldsymbol{C}$. botulinum spores by removing carcasses from pastures and disposing of them correctly (SOUZA \& LANGENEGGER 1987). Open-air decomposition of animal carcasses suspect of botulism results in approximately $46.5 \%$ of the $\boldsymbol{C}$. botulinum spores and/or toxins in their ribs. When these carcasses are dismembered followed by pre-composting in static piles without aeration for 50 days at $40.5^{\circ} \mathrm{C}$ to $52.4^{\circ} \mathrm{C}$, there is decomposition of approximately $60 \%$ of the carcasses without the presence of spores or botulinum toxin in the ribs (RIBAS et al. 1994; CURCI et al., 2007).

\section{CONCLUSION}

Botulism remains an important disease in ruminants in Brazil. However, its epidemiology in cattle has markedly changed, with decreases in the cases associated with osteophagia resulting from mineral deficiencies and increases in outbreaks related to the supply of contaminated feed.

\section{ACKNOWLEDGEMENTS}

The authors are thankful for the financial support from Fundação de Amparo à Pesquisa do Estado de Minas Gerais (FAPEMIG (APQ-02304-13)), Coordenação de Aperfeiçoamento de Pessoal de Nível Superior (CAPES/Proex) and Conselho Nacional de Desenvolvimento Científico e Tecnológico (CNPq).

\section{REFERENCES}

ALBERNAZ, T.T. et al. Botulism from hydric origin in buffaloes in the State of Para, Brazil. Veterinária e Zootecnia, v.18, n.4, supl.3, p.779-782, 2011. Available from: <http://www.fmvz.unesp.br/rvz/ index.php/rvz/article/view/440/334>. Accessed: Mar. 06, 2016.

ANNIBALLI, F. et al. Management of animal botulism outbreaks: from clinical suspicion to practical countermeasures to prevent or minimize outbreaks. Biosecurity and Bioterrorism, v.11, S1, S191-S199, 2013. Available from: <http://www.ncbi.nlm.nih.gov/ pubmed/23971806>. Accessed: Mar. 06, 2016.

AOKI, K.R. et al. Mode of action of botulinum neurotoxins: current vaccination strategies and molecular immune recognition. Critical reviews in immunology, v.30, p.167-187, 2010. Available from: $<$ http://www.ncbi.nlm.nih.gov/pubmed/20370628>. Accessed: Mar. 06, 2016. doi: 10.1615/CritRevImmunol.v30.i2.50

ARRUDA, Z.P. A bovinocultura de corte no Brasil e perspectivas para o setor. Campo Grande: Embrapa - CNPGC, 1994. 28p.

BRASIL. Ministério da Agricultura, Pecuária e Abastecimento. Manual de Legislação: Programas Nacionais de Saúde Animal do Brasil. Secretaria de Defesa Agropecuária. Departamento de Saúde Animal. Brasília: MAPA/SDA/ DSA, 2009. 440p.

BRASIL. Ministério da Agricultura. Portaria n. 49, 12 de maio de 1997. Diário Oficial da União, 16 de maio de 1997. Seção 1, p.10168-10169.

CÂMARA, A.C.L. et al. Epidemiology, Clinical Signs, Laboratorial and Pathological Findings in Eight Outbreaks of Botulism in Cattle in Rio Grande do Norte State, Northeastern Brazil. Acta Scientiae Veterinariae, v.42, p.1-8, 2014. Available from: <http://www. ufrgs.br/actavet/42/PUB\%201200.pdf>. Accessed: Jan. 10, 2015.

CÂMARA, A.C.L. et al. Outbreaks of botulism in dairy cattle from Rio Grande do Norte, Northeastern Brazil. Veterinária e Zootecnia, p.18, p.705-708, 2011. Available from: <http:// www.fmvz.unesp.br/rvz/index.php/rvz/article/view/440/334>. Accessed: Jan. 10, 2015. 
CARCIOFI, A.C. et al. Estudo etiológico e epidemiológico da "doença da vaca caída". Revista de Educação Continuada em Medicina Veterinária e Zootecnia (CRMV-SP), v.6, n.1/3, p.28-41, 2003.

CARVAlHO, A.Q. et al. Spontaneous poisoning by Senna obtusifolia in cattle of the southern Pantanal. Pesquisa Veterinária Brasileira, v.34, p.147-152, 2014. Available from: <http://www. scielo.br/pdf/pvb/v34n2/v34n2a09.pdf>. Accessed: Feb. 12, 2016. doi: 10.1590/S0100-736X2014000200009.

COELHO, H.E. et al. Botulism in buffalos. Veterinária Notícias, v.2, n.1, p.67-70, 1996.

COSTA, G.M. et al. Botulism in dairy cattle in southern Minas Gerais, Brazil. Ciência Rural, v.38, p.2068-2071, 2008. Available from: $\quad<$ http://www.scielo.br/scielo.php?script=sci_arttext\&pid $=$ S0103-84782008000700045 $>$. Accessed: Jan. 10, 2015. doi: $10.1590 / \mathrm{S} 0103-84782008000700045$.

CURCI, V.C.L.M. et al. The effect of composting cattle carcasses on botulinum spores and toxin content. Pesquisa Veterinária Brasileira, v.27, n.4, p.157-161, 2007. Available from: <http:// www.scielo.br/scielo.php?script $=$ sci_arttext\&pid $=$ S 0100 736X2007000400005>. Accessed: Jan. 10, 2016. doi: 10.1590/ S0100-736X2007000400005.

DOVER, N. et al. Molecular characterization of a novel botulinum neurotoxin type H gene. Journal of Infectious Diseases, v.209, p.192-202, 2014. Available from: <http://www.ncbi.nlm.nih.gov/ pubmed/24106295>. Accessed: Jan. 10, 2015.

DUTRA I.S. et al. Botulism in beef and dairy cattle fed with poultry litter. Pesquisa Veterinária Brasileira, v.25, p.115-119, 2005. Available from: <http://www.scielo.br/scielo.php?pid=S0100736X2005000200009\&script=sci_arttext $>$. Accessed: Jan. 10, 2015. doi: 10.1590/S0100-736X2005000200009.

DUTRA I.S. et al. Botulism outbreaks in cattle in Brazil associated with contaminated water. Pesquisa Veterinária Brasileira, v.21, p.43-48, 2001. Available from: <http://dx.doi.org/10.1590/S0100736X2001000200002>. Accessed: Jan. 10, 2016. doi: 10.1590/ S0100-736X2001000200002.

DUTRA, I.S. et al. Botulismo de origem hídrica em bovinos no Brasil. In: WORLD BUIATRICS CONGRESS, 16., 1990 , Salvador, Ba. Proceedings... Salvador: WBC, 1990. p.547- 550.

DUTRA, I.S.; DÖBEREINER, J. Fatos e teorias sobre a doença da vaca caída: botulismo. Hora Veterinária, v.84, p.7-10, 1995.

KRÜGER, M. et al. Chronic botulism in a Saxony dairy farm: sources, predisposing factors, development of the disease and treatment possibilities. Anaerobe, v.28, p.220-225, 2014. Available from: <http://www.ncbi.nlm.nih.gov/pubmed/24997242>. Accessed: Feb. 12, 2016. doi: 10.1016/j.anaerobe.2014.06.010.

KRÜGER, M. et al. Visceral botulism at dairy farms in Schleswig Holstein, Germany: prevalence of Clostridium botulinum in feces of cows, in animal feeds, in feces of the farmers, and in house dust. Anaerobe, v.18, p.221-223, 2012. Available from: <http://www. ncbi.nlm.nih.gov/pubmed/22200452>. Accessed: Feb. 12, 2016. doi: $10.1016 /$ j.anaerobe.2011.12.013

RODLOFF, A.C.; KRÜGER M. Chronic Clostridium botulinum infections in farmers. Anaerobe, v.18, p.226-228, 2012. Available from: <http://www.ncbi.nlm.nih.gov/pubmed/22197952t>. Accessed: Feb. 12, 2016. doi: 10.1016/j.anaerobe.2011.12.011.

LANGENEGGER, J.; DÖBEREINER J. Botulismo enzoótico em búfalos no Maranhão. Pesquisa Veterinária Brasileira, v.8, p.37-42, 1988.

LEDERMANN, W.D. The history of Clostridium botulinum. Revista Chilena de Infectología, v.20, p.39-41, 2003. Available from: $<$ http://www.scielo.cl/scielo.php?script=sci_arttext\&pi $\mathrm{d}=\mathrm{S} 0716-10182003020200011>$. Accessed: Jan. 10, 2015. doi: 10.4067/S0716-10182003020200011.

LEMOS, R.A.A. Enfermidades do sistema nervosa de bovinos de corte da região centro-oeste e sudeste do Brasil. 2005. 143f. Tese (Doutorado em Medicina Veterinária Preventiva) - Curso de Pós-graduação em Medicina Veterinária Preventiva, Universidade Estadual Paulista "Julio Mesquita Filho", SP.

LOBATO, F.C.F. et al. Botulism in ruminants being fed with poultry litter. Ciência Rural. v.38, p.1176-1178, 2008. Available from: <http://dx.doi.org/10.1590/S0103-84782008000400046>. Accessed: Jan. 10, 2016. doi: 10.1590/S0103-84782008000400046.

LOBATO, F.C.F. et al. Botulismo em bovinos causado pelo Clostridium botulinum tipo B. Arquivo Brasileiro de Medicina Veterinária e Zootecnia, v.40, p.445-446, p.445-445, 1988.

LOBATO, F.C.F. et al. Clostridial infection in farm animals. Veterinária e Zootecnia, v.20, p.29-48, 2013. Available from: $<$ http://www.fmvz.unesp.br/rvz/index.php/rvz/article/view/651>. Accessed: Jan. 10, 2015.

LOBATO, F.C.F. et al. Clostridiosis of small ruminants. Revista Portuguesa de Ciência Veterinária, v.102, p.23-34, 2007. Available from: <http://www.fmv.utl.pt/spcv/PDF/pdf6_2007/2334.pdf $>$. Accessed: Jan. 10, 2015.

LOBATO, F.C.F. et al. Potencia de toxoides botulinicos bivalentes $\mathrm{C}$ e D produzidos e comercializados no Brasil. Revista Brasileira de Medicina Veterinária, v.20, n.1, p.35-38, 1998.

MABONI, F. et al. Occurrence of botulism in feedlot bovine in Rio grande do Sul state/Brazil. Revista Ciência Animal, v.11, p.11-13, 2010. Available from: <http://revistas.ufg.emnuvens.com. br/vet/article/viewFile/3336/8376>. Accessed: Jan. 10, 2016. doi: 10.5216/cabv11i4.333.

NOVAIS, E.P.F. Doenças com sinais neurológicos em ovinos e caprinos no Distrito Federal e entorno. 2013. 115f. Dissertação (Mestrado em Saúde Animal) - Curso de Pós-graduação em Saúde Animal, Universidade de Brasília, DF.

ORTOLANI, E.L. et al. Botulism outbreak associated with poultry litter consumption in three Brazilian cattle herds. Veterinary and Human Toxicology, v.39, n.2, p.89-92, 1997. Available from: $<$ http://www.ncbi.nlm.nih.gov/pubmed/9080634>. Accessed: Jan. 10, 2015.

ORTOLANI, E.L. Panorama epidemiológico da mortalidade enzoótica de bovinos adultos no Brasil e no Paraguai: retrospectiva de levantamentos. Hora Veterinária, v.12, p.20-25, 1993.

PEDROSO, P.M.O. et al. Clinical and pathological aspects in cattle affected by rabies with special reference to the rabies antigen mapping by immunohistochemistry. Pesquisa Veterinária 
Brasileira, v.29, p.899-904, 2009. Available from: <http://www. scielo.br/pdf/pvb/v29n11/a06v2911.pdf>. Accessed: Feb. 12, 2016. doi: 10.1590/S0100-736X2009001100006.

RAYMUNDO, D.L. et al. Clostridial diseases diagnosed in herbivores in Southern Brazil. Acta Scientiae Veterinariae, v.42, pub.1204, 2014. Available from: <http://www.ufrgs.br/actavet/42/ PUB\%201204.pdf>. Accessed: Feb. 12, 2016

RIBAS, A.I. et al. Detecção de esporos de Clostridium botulinum em costelas de cadáveres decompostos de bovinos. In: CONGRERSSO BRASILEIRO DE MEDICINA VETERINÁRIA, 23., 1994, Olinda, Pe. Anais do Congrersso Brasileiro de Medicina Veterinária. Olinda: Sociedade Brasileira de Medicina Veterinária, 1994. p.142.

RIBAS, N.L.K.S. et al. Diseases of the nervous system of cattle in Mato Grosso do Sul, Brazil: 1082 cases. Pesquisa Veterinária Brasileira, v.33, n.10, p.1183-1194, 2013. Available from: <http:// www.scielo.br/pdf/pvb/v33n10/03.pdf>. Accessed: Feb. 12, 2016.

RIET-CORREA, F. et al. Botulism by Clostridium botulinum type $\mathrm{C}$ in goats associated with osteophagia. Small Ruminant Research, v.106, p.201-205, 2012. Available from: $<$ http://dx.doi. org/10.1016/j.smallrumres.2012.03.010>. Accessed: Feb. 12, 2016. doi: 10.1016/j.smallrumres.2012.03.010.

SCHOCKEN-ITURRINO R.P.; AVILA, F.A. Botulism in confined bovine caused by the intake contamined poultry litter. Arquivo Brasileiro de Medicina e Zootecnia, v.43, p.279-280, 1991. Available from: <http:/www.scielo.br/scielo.php?script=sci artt ext\&pid=S0102-09351999000300005>. Accessed: Jan. 10, 2015. doi: 10.1590/S0102-09351999000300005.

SILVA, T.M.D. et al. Occurrence and distribution of Clostridium botulinum type $\mathrm{C}$ and $\mathrm{D}$ spores in buffalo breeding areas of the
Baixada Maranhense, Maranhão, Brazil. Pesquisa Veterinária Brasileira, v.18, n.3-4, 1998. Available from: <http://www.scielo. br/scielo.php?pid=S0100-736X1998000300007\&script $=$ sci arttext>. Accessed: Feb. 12, 2016. doi: 10.1590/S0100736X1998000300007.

SOUILLARD, R. et al. Occurrence of $\boldsymbol{C}$. botulinum in healthy cattle and their environment following poultry botulism outbreaks in mixed farms. Veterinary Microbiology, v.22, p.142-5, 2015. Available from: <http://www.ncbi.nlm.nih.gov/ pubmed/26298858>. Accessed: Feb. 12, 2016. doi: 10.1016/j. vetmic.2015.07.032.

SOUZA, A.M. et al. Spores and toxins of Clostridium botulinum in raining ponds used as water supply for cattle in pastures in the Araguaia Valley, State of Goiás, Brazil. Pesquisa Veterinária Brasileira, v.26, p.133-138, 2006. Available from: <http://dx.doi.org/10.1590/S0100736X2006000300001>. Accessed: Jan. 10, 2015.

SOUZA, A.M.; LANGENEGGER, J. Esporos de Clostridium botulinum em torno de cadáveres decompostos de bovinos em pastagens no sul de Goiás. Pesquisa Veterinária Brasileira, v.7, p.17-22, 1987. Available from: <http://www.scielo.br/scielo. php script $=$ sci arttext\&pid $=\mathrm{S} 0100-736 \times 2006000300001>$. Accessed:Jan. 10,2015. doi: 10.1590/S0100-736X2006000300001.

TOKARNIA, C.H. et al. Botulismo em bovinos no Piauí, Brasil. Pesquisa Agropecuária Brasileira, v.5, p.465-472, 1970 Available from: <http://seer.sct.embrapa.br/index.php/pab/article/ view/17865>. Accessed: Jan. 10, 2015.

VELOSO NETO, H.F. et al. Botulism outbreaks in cattle in the region of Garanhuns - PE. Veterinária e Zootecnia (UNESP), v.18, n.4, p.853-857, 2011. Available from: <http://www.fmvz. unesp.br/rvz/index.php/rvz/article/view/440/334>. Accessed: Jan. 10, 2016. 